\title{
Fly Ash Utilization in Structural Concrete for Sustained Construction
}

\author{
${ }^{1}$ Rana A, ${ }^{2}$ Sagar R, \\ ${ }^{1}$ Assistant Professor \\ ${ }^{2} \mathrm{M}$. Tech Student \\ Department of Civil Engineering \\ Shri Venkateshwara University Gajraula \\ Uttar Pradesh, India
}

\begin{abstract}
Carbon content in fly ash is important consideration for use with cement; it should be as low as possible. The fineness of fly ash should be as high as possible. The silica contained in fly ash should be present in finely divided state since it combines slowly over a very long period with the lime liberated during the hydration of the cement. Curing the temperature of 38 degree has been found to greatly accelerate its contribution to the strength of concrete

Pulverized fuel ash is available in large quantities in the country as a waste product from a number of thermal power stations and industrial plants using pulverized or crushed or ground coal or lignite as fuel for boilers

Pulverized fuel ash to be used as Pozzolana in cement, cement mortar and concrete in accordance with this standard shall be fly ash only which may be either in as collected condition or beneficiated, segregated or processed.

This standard was first published in 1966 in three parts to cater to the requirements of fly ash for three specific uses: Part 1 covering use of fly ash as a Pozzolana, Part 2 covering use of fly ash as an admixture for concrete, and Part 3 covering use of fly ash as fine aggregate for mortar and concrete

Slump loss of concrete increases with increase in water cement ratio of concrete. For water cement ratio 0.35 without any admixtures, initial slump cannot be measured by slump cone test as it is very less. Ultimate compressive strength of concrete decreasing with increase in ratio of concrete. Slump loss of concrete goes on increasing with increase of quantity of fly ash. The $10 \%$ and $20 \%$ replacement of cement with fly ash shows good compressive strength for 28 days. The $30 \%$ replacement of cement with fly ash ultimate compressive strength of concrete decreases.
\end{abstract}

Key Words: Fly Ash, Concrete, Workability, Strength, Curing.

\section{INTRODUCTION}

Fly ash or pulverized fuel ash is the residue from the combustion of pulverized coal collected by mechanical or electrostatic separators from the fuel gases or power plant. It is constitutes about $75 \%$ of the total ash produced. The properties and composition of fly ash vary widely, not only between different plants but from hour to hour in the same plant. Its depends on type of fuel burnt and on the variation of load on the boiler. Fly ash obtained from cyclone separator is comparatively coarse and contain and large proportion of unbent fuel, whereas that obtained from electrostatic precipitators is relatively fine having a specific surface of about $3500 \mathrm{~cm} 2 / \mathrm{g}$ and may be as high as 500 $\mathrm{cm} 2 / \mathrm{g}$. Normally it is rather finer than Portland cement.fly ash consist generally of spherical particles, some of which may be like glass and hollow and of irregularly shaped particles of unbent fuel carbon. It may vary in colors from light grey to dark grey or even brown.

Carbon content in fly ash is important consideration for use with cement; it should be as low as possible. The fineness of fly ash should be as high as possible. The silica contained in fly ash should be present in finely divided state since it combines slowly over a very long period with the lime liberated during the hydration of the cement. Curing the temperature of 38 degree has been found to greatly accelerate its contribution to the strength of concrete. Curing at high pressure and temperature in autoclave promotes the reaction between the lime liberated during the hydration of cement and the silica in the fly ash. However, this reaction should tend to prevent the release of free lime to reduced efflorescence.

Fly ash is supplied in two grades; grade I grade II. There general use is incorporating it in cement mortar and concrete and in lime Pozzolana mixture. However, only grade $\mathrm{I}$ is recommended for manufacture of Pozzolana cement.

Pulverized fuel ash is available in large quantities in the country as a waste product from a number of thermal power stations and industrial plants using pulverized or crushed or ground coal or lignite as fuel for boilers. The effective use of pulverized fuel ash as a Pozzolana in the manufacture of and for part replacement of cement, as an admixture in cement, cement mortar and concrete, lime Pozzolana mixture and products such as fly ash lime bricks, concrete blocks, asbestos cement products, etc, have been established in the country. Investigations of Indian pulverized fuel ashes have indicated greater scope for their utilization as a construction material. Greater utilization of pulverized fuel ash will lead to not only saving of scarce construction materials but also assist in solving the problem of disposal of this waste product. The investigations have also indicated the necessity to provide proper collection methods for fly ash so as to yield fly ash of quality and uniformity which are prime requirements of fly ash for use as a construction mate.

\section{OBJECTIVE OF THE STUDY:}

The objectives of the study are as follows.

1.To provide the durability and strength from using the flyash. 
2. To improves the strength and segregation of the concrete and makes it easier to pump from flyash utilization.

\section{METHODOLOGY}

The research paper done on the basis of the methodology. Steps was followed from methodology till analysis of the results.

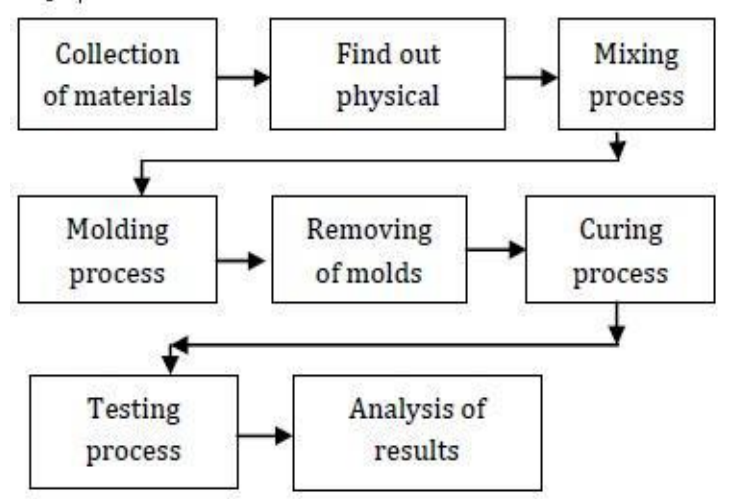

Fig-1.Block Diagram of Working Process

\section{LABORATORY EVALUATION}

Table No.-1. Compressive Strength of Concrete with Different W/C Ratio

\begin{tabular}{|c|c|c|c|}
\hline $\begin{array}{l}\text { Sr. } \\
\text { No. }\end{array}$ & \begin{tabular}{c|} 
w/c \\
ratio
\end{tabular} & $\begin{array}{c}\text { Compressive Strength } \\
\left(\mathrm{N} / \mathbf{m m}^{2}\right)\end{array}$ & $\begin{array}{l}\text { Avg. Compressive } \\
\text { Strength (N/mm) }\end{array}$ \\
\hline 1 & \multirow[t]{3}{*}{0.35} & 21.3 & \multirow[t]{3}{*}{22.4} \\
\hline 2 & & 23.7 & \\
\hline 3 & & 22.2 & \\
\hline 4 & \multirow[t]{3}{*}{\begin{tabular}{|l|}
0.45 \\
\end{tabular}} & 20.6 & \multirow[t]{3}{*}{20.83} \\
\hline 5 & & 20.8 & \\
\hline 6 & & 21.1 & \\
\hline 7 & \multirow[t]{3}{*}{0.55} & 8.97 & \multirow[t]{3}{*}{11.08} \\
\hline 8 & & 12.28 & \\
\hline 9 & & 12.0 & \\
\hline
\end{tabular}

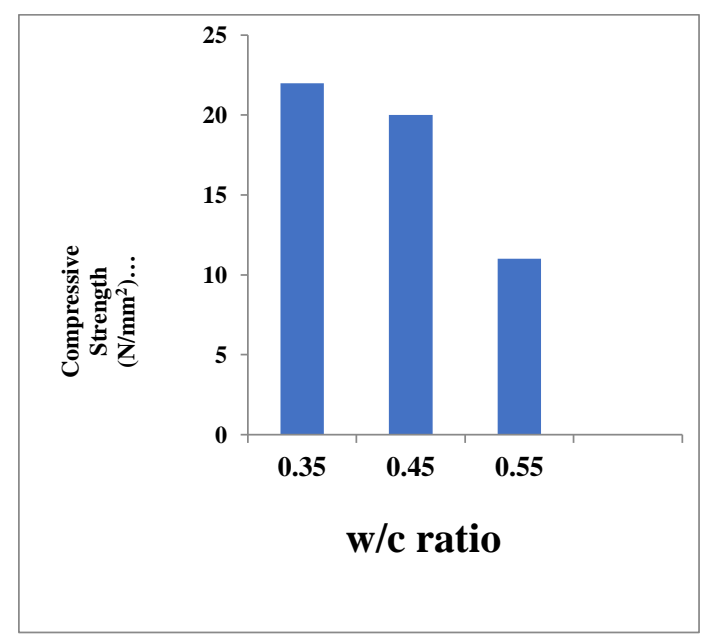

Fig-2. Variation in Compressive Strength for Different Water Cement Ratio
Table No-2. Slump of Concrete with Different W/C Ratio

\begin{tabular}{|l|c|c|c|}
\hline w/c ratio & .35 & .45 & .55 \\
\hline Slump in $\mathrm{mm}$ & 0 & 30 & 160 \\
\hline
\end{tabular}

Table No-3. Compressive strength for different proportion of fly ash after 7 days curing

\begin{tabular}{|c|c|c|c|}
\hline Sr.No. & $\%$ of fly ash & $\begin{array}{c}\text { Compressive strength } \\
\left(\mathrm{N} / \mathrm{mm}^{2}\right)\end{array}$ & $\begin{array}{c}\text { Avg. Compressive } \\
\text { strength } \\
\left(\mathrm{N} / \mathbf{m m}^{2}\right)\end{array}$ \\
\hline 1 & \multirow{3}{*}{$0 \%$} & 27.5 & \multirow{3}{*}{23.5} \\
\hline 2 & & 23.6 & \\
\hline 3 & & 19.4 & \\
\hline 4 & \multirow[b]{3}{*}{$10 \%$} & 22.5 & \multirow{3}{*}{26.20} \\
\hline 5 & & 28.62 & \\
\hline 6 & & 27.5 & \\
\hline 7 & \multirow{3}{*}{$20 \%$} & 27.2 & \multirow{3}{*}{25.3} \\
\hline 8 & & 22.8 & \\
\hline 9 & & 25.9 & \\
\hline 10 & \multirow{4}{*}{$30 \%$} & 23.08 & \multirow{4}{*}{20.91} \\
\hline & & & \\
\hline 11 & & 20.12 & \\
\hline 12 & & 19.54 & \\
\hline
\end{tabular}

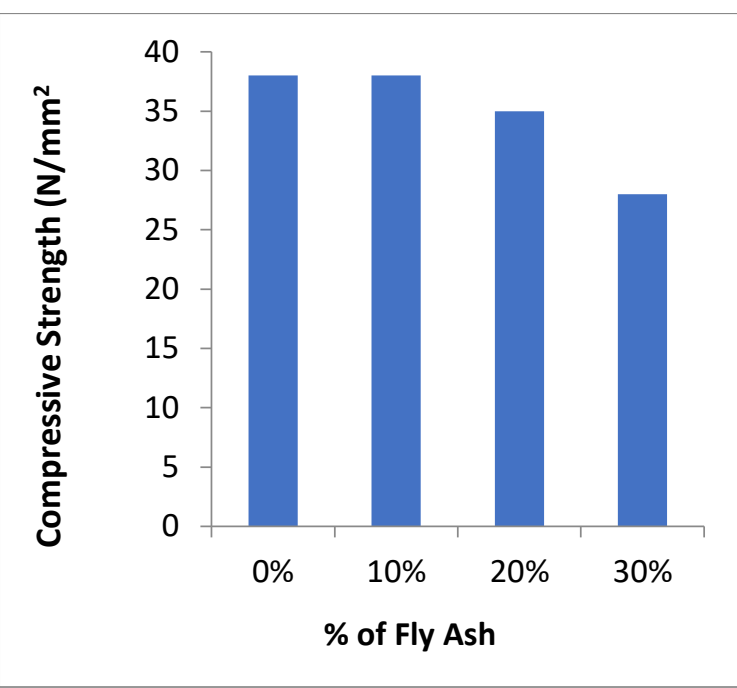

Fig-3.Compressive Strength for Different Proportion Of Fly Ash After 7 Days Curing

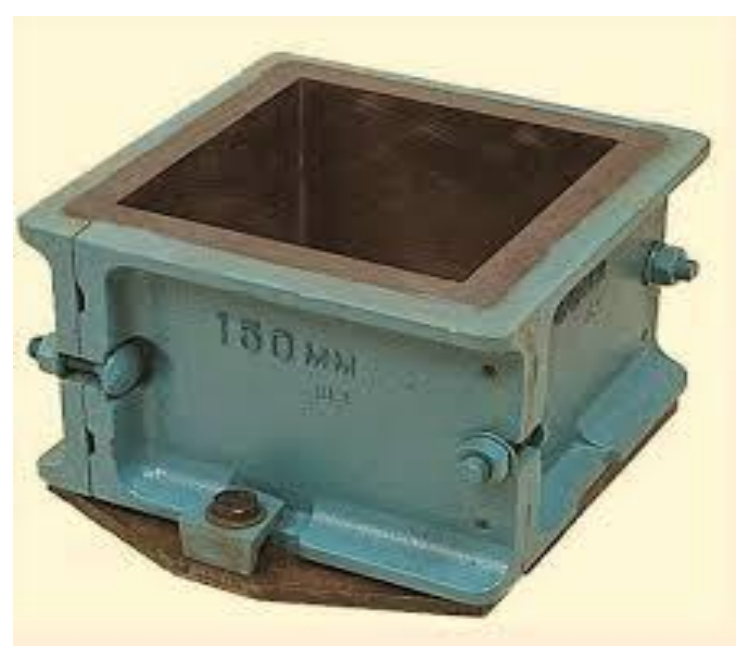

Fig-4. Mould of concrete cube 


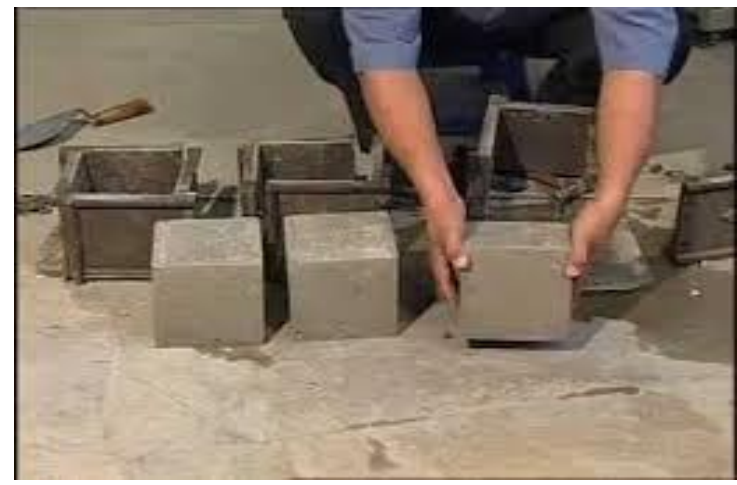

Fig-5. Sample of Concrete Cube

Table No-4 Compressive strength for different proportion of fly ash after 28 days curing

\begin{tabular}{|c|c|c|c|}
\hline Sr. No. & $\%$ Of Fly Ash & $\begin{array}{c}\text { Compressive Strength } \\
\left(\mathrm{N} / \mathbf{m m}^{2}\right)\end{array}$ & $\begin{array}{c}\text { Avg. compressive } \\
\text { strength } \\
\left(\mathrm{N} / \mathbf{m m}^{2}\right)\end{array}$ \\
\hline 1 & \multirow{3}{*}{$0 \%$} & 38.17 & \multirow{3}{*}{38.96} \\
\hline 2 & & 38.48 & \\
\hline 3 & & 40.25 & \\
\hline 4 & \multirow{3}{*}{$10 \%$} & 41.87 & \multirow{3}{*}{43.24} \\
\hline 5 & & 44.59 & \\
\hline 6 & & 43.28 & \\
\hline 7 & \multirow{3}{*}{$20 \%$} & 38.95 & \multirow{3}{*}{37.78} \\
\hline 8 & & 34.5 & \\
\hline 9 & & 39.89 & \\
\hline 10 & \multirow{3}{*}{$30 \%$} & 33.88 & \multirow{3}{*}{31.46} \\
\hline 11 & & 28.92 & \\
\hline 12 & & 31.58 & \\
\hline
\end{tabular}

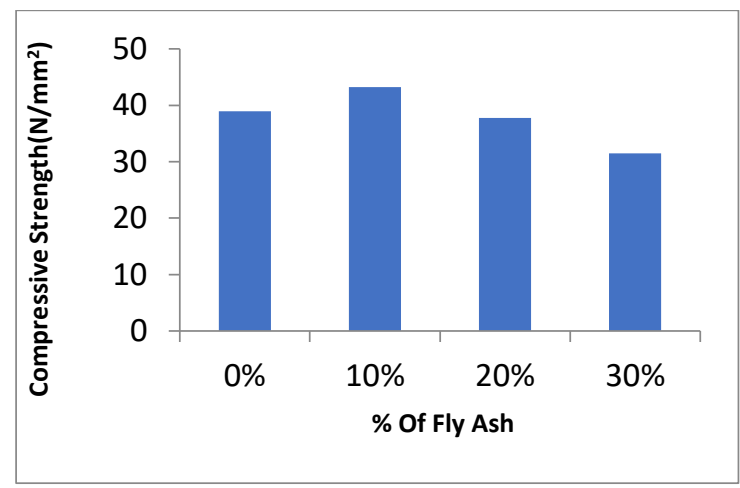

Fig-6. Compressive strength for different proportion of fly ash after 28 days curing

\section{RESULTS}

The various chemical plants treating wastewater through adsorption, activated carbon is frequently used as an adsorbent. However, in view of the higher cost of activated carbons and difficulties associated with regeneration, attempts have been made by various workers to use fly ash as low-cost materials and it remains a potential low-cost adsorbent for the future.

- Thus, by results we can see as amount of fly ash is increased, consistency decreased. And as amount of fly ash is increased in mix, it requires less water as compare to cement.
- Thus by result it can also be seen that as amount of fly ash increased in cement, initial setting time also increased and it take more time to settle.

- It can also be seen that as amount of fly ash increased compressive strength decreased, up to $30-40 \%$ is safe to use in concrete mix and $50 \%$ fly ash cement concrete has not enough compressive strength to use for construction.

\section{CONCLUSION}

This research concludes the study of the effect of fly ash on the properties of concretell for nominal mix of M25 grade of concrete are as follows.

1. Slump loss of concrete increases with increase in water cement ratio of concrete.

2. For water cement ratio 0.35 without any admixtures, initial slump cannot be measured by slump cone test as it is very less.

3. Ultimate compressive strength of concrete decreasing with increase in ratio of concrete.

4. Slump loss of concrete goes on increasing with increase of quantity of fly ash.

5. The $10 \%$ and $20 \%$ replacement of cement with fly ash shows good compressive strength for 28 days.

6. The $30 \%$ replacement of cement with fly ash ultimate compressive strength of concrete decreases.

\section{REFRENCES}

[1] Dr. S L Patil, J N Kale, S. Suman at el. [1] (2012) Fly Ash Concrete: A Technical Analysis for Compressive Strength.

[2] ARUN KUMAR, A. S. SANTHI, G. MOHANGANESH at el. [2] (2012) Various Utilization of Fly Ash and Its Properties on Concrete.

[3] Dr.Suhas V. Patil, Suryakant C. Nawle, Sunil J. Kulkarni at el. [3] (2013) Industrial Applications of Fly Ash.

[4] Hong Zhu Quan and Hideo Kasami at el. [4] (2014) Experimental Study On Durability Improvement Of Fly Ash Concrete With Durability Improving Admixture.

[5] Vinit Kumar Singh, Vikas Srivastava, Alvin Harrison at el. [5] (2015) Effect of Fly Ash as Partial Replacement of Cement in PPC Concrete.

[6] Vinod Goud, Niraj Soni at el. [6] (2016) Partial Replacement of Cement with Fly Ash in Concrete and Its Effect.

[7] Khushal Chandra Kesharwani, Amit Kumar Birwa's, Anis Chaurasiya1, Ahsan Rabbani at el. [7] (2017) Experimental Study on Use of Fly Ash in Concrete.

[8] Anjali Yadav, Nikhil Kumar Yadav at el. [8] (2017) Study of Fly Ash Cement Concrete Pavement

[9] IS 456:2000- Plain and Reinforced Concrete-Code of Practice. (Fourth Revision) 